DOI https://doi.org/10.30525/978-9934-26-040-7-6

\title{
СОЦІАЛЬНА ВІДПОВІДАЛЬНІСТЬ УКРАЇНСЬКОГО СУСПІЛЬСТВА ПЕРЕД ДНЕМ СОБОРНОСТІ УКРАЇНИ: ВІД ПОЧАТКУ ДО СЬОГОДЕННЯ
}

\author{
Коритко Л. Я. \\ доктор юридичних наук, дочент, \\ завідувач кафедри загальноправових та гуманітарних дисциплін \\ Івано-Франківського юридичного інституту \\ Національного університету «Одеська юридична академія»
}

\begin{abstract}
Антонюк У. В.
кандидат юридичних наук, дочент, доцент кафедри изивільного та господарського права і процесу Івано-Франківського юридичного інституту Наиіонального університету «Одеська юридична академія»
\end{abstract}

\section{Джуган В. О.}

кандидат юридичних наук, дочент, доцент кафедри ичивільного та господарського права і процесу Івано-Франківського юридичного інституту Національного університету «Одеська юридична академія» м. Івано-Франківськ, Украӥна

Аналіз подій історичного розвитку Української державності та етапів святкування Дня Соборності України свідчить про важливе політико-правове та політично-історичне значення дати 22 січня 1919 р., коли відбулося об'єднання Української Народної Республіки та Західноукраїнської Народної Республіки. У цей день століттями роз'єднаний український народ визволився 3 неволі (Наддніпрянщина вийшла зі складу Російської імперії, Західна Україна - 3 АвстроУгорської імперії) та об'єднався в єдину Українську державу. Акт злуки був свідченням єдності, бо в управлінні державою такої єдності так і не відбулося на той час, проте Акт Соборності вказував на визначену форму держави Україна. «Безпорадність проводу впливала на загальний настрій, - писала сучасниця тих подій, історик Наталя Полонська-Василенко. - Україна, затиснута між двома потужними силами - Атлантою $з$ півдня і большевизмом 3 півночі, - не мала сил 
для боротьби. Військо розбігалося, ширилося безладдя. У таких умовах пройшла майже непоміченою подія, яка мала велике ідейне значення: свято Соборності України. 22 січня 1919 р. на Софійській площі проголошено УНР і ЗУНР... Але під тиском невідрадних подій свято пройшло сухо, тихо» [1, с. 420].

Питання тематики Української державності 1917-1921 років досліджували такі українські науковці: Верстюк В.Ф., Гай-Нижник П.П., Гирич І.Б., Гончаренко А.О., Тимченко Я.Ю., Шемшученко Ю.С., Кульчицький С.В., Лоський І.К., Любарець А.В., Михайлик М.В., Монкевич Б.Г., Полонська-Василенко Н.Д., Сергійчик В.І., Файзулін Я.М. тощо. Питання соціальної відповідальності досліджували Аземша І.Б., Безрукова О.А., Грищук В.К., Іванова Т.В., Кіріченко О.Ю., Куценко В.Й., Охріменко О.О., Пехник А.В., Рабінович П.М., Хавронюк М.І., Швець Д.В. та інші, однак питання соціальної відповідальності впродовж формування Соборної української держави науковцями чітко не окреслені та $є$ предметом даного дослідження.

Доповідь присвячена дослідженню питання сутності та змісту соціальної відповідальності українського суспільства перед Днем Соборності України. Досягнення цієї мети поставило наступні завдання даної роботи: вказати етапи формування Дня соборності України від 1919 до 2021 року; охарактеризувати роль соціальної відповідальності суспільства у дні складних історичних подій та формування Української держави та зробити відповідні висновки.

Історія Дня Соборності України має безпосереднє відношення до українського державотворення у $\mathrm{XX}$ ст. та охоплює ряд етапів: зародження ідеї соборності починалося ще 3 часів Візантії. Ї̈̈ реалізацією займалися українські гетьмани: Богдан Хмельницький, Іван Мазепа, Петро Дорошенко, Пилип Орлик, хоча ще в XVIII - поч. XX ст.ст. українські землі були поділені між Польщею, Московією, Румунією, Австро-Угорщиною; підготовка Акту злуки - після ухвалення ІІІ-го Універсалу Української Центральної Ради 7 листопада 1917 р. була проголошена Українська Народна Республіка, однак у складі Російської Республіки, а 13 листопада 1918 р. було утворено Західноукраїнську Народну Республіку. 3 тих пір між органами управління УНР та ЗУНР систематично відбувалися переговори про реалізацію ідеї Соборної України; проголошення Акту Злуки - після ухвалення IV-го універсалу 9 січня 1918 р., яким було проголошено незалежну Українську Народну Республіку на його виконання та об'єднання з ЗУНР на Софіївській площі 22 січня 1919 р. було проведено Акт Злуки УНР та ЗУНР. Цей день офіційно було 
проголошено Днем Соборності України, що стало великим виявом волі українців, свідченням їхнього самовизначення та становлення політичної нації; у міжвоєнний період (осінь 1919 року - 1939 роки) об'єднання проводилося юридично та політично, але не фактично. У військовий час уряди та військове командування ЗУНР та УНР дбали лише про місцеві інтереси, а не про єдність та соборність України. Україна тоді належала до складу: Польщі, Румунії, Чехословаччини, СРСР; перше офіційне святкування Дня Соборності відбулося 22 січня 1939 р. у Карпатській Україні (м. Хуст), це був не звичайний вияв протесту, а пряма демонстрація місцевим населенням (30000 чоловік) всієї території Карпатської України виразу ідеї єднання; 21 січня 1990 р., напередодні Дня Соборності України патріотичними силами був організований «живий ланцюг», ця масова акція між Києвом, Львовом та Івано-Франківськом символізувала єднання українців та східних і західних земель України. Акція «Живого ланцюга» у цей же час була підтримана і в Харкові; в незалежній Україні офіційне свято День соборності України був запроваджений Указом Президента України Л. Кучми «Про День соборності України» від 21 січня 1999 р. «Живі ланцюги» відродились в 2000-ні роки. Так, в 2008-2011 роках їх утворювали українці в Києві на мосту Патона, а найбільший такий «ланцюг» був у 2011 р., коли на цей міст прийшло понад 1000 учасників, до нього приєдналися також і в інших містах; тимчасові зміни 32011 року, коли 30 грудня 2011 р. Президент України В. Янукович своїм указом скасував указ Президента В. Ющенка від 2005 р. про встановлення Дня Свободи 22 листопада (присвяченого подіям Помаранчевої революції) та указ Л. Кучми від 1999 р. про встановлення Дня соборності України 22 січня, та водночас оголосив 22 січня Днем Соборності та Свободи України; офіційне відновлення цього свята відбулося підписанням указу Президентом України П. Порошенком «Про День Соборності України» від 13 листопада 2014 р., згідно з яким свято відзначають «...щорічно 22 січня - у день проголошення в 1919 році Акта злуки Української Народної Республіки та Західноукраїнської Народної Республіки День Соборності України» [2], а день Соборності та Свободи України ним було скасовано. Шостий чинний Президент України В. Зеленський 22 січня 2020 та 2021 p.p. також вітав українців з Днем Соборності України та наголошував не лише на об'єднанні територій, а й на об'єднанні українців. Згадував про фактичну втрату Криму та частини Донбасу, однак зсилаючись на Акт Злуки оптимістично відзначив, що в майбутньому українці зможуть стати творцями нового Акта Злуки [3]. 
В цей час українці також робили «живі ланцюги» у різних куточках України.

Означені історичні та політико-правові події свідчать про те, що український народ роками визволявся 3 неволі. Дата 22 січня щороку нагадує українському суспільству про перше проголошення незалежної Української Республіки та Акту Злуки її з ЗУНР в умовах російської військової агресії. А в сучасному суспільстві наявні процеси глобалізації та об'єднання національних утворень в єдину світову систему, але це відбувається в правових явищах та в питаннях міжнародної політики. А в Україні потрібно об'єднати зусилля для збереження територіальної цілісності та безпеки держави, а також повернення втрачених зовнішнім агресором територій. Питання соціальної відповідальності є базою, на якій побудована практично вся система взаємовідносин, зокрема в українському суспільстві. День Соборності України повинен втілювати розуміння соціальної відповідальності всього українського суспільства за долю держави у складні періоди державотворення, а також цей день дає можливість пам'ятати про подвиг добровольців (української молоді) у бою під Крутами, які, відчуваючи відповідальність, стримали наступ більшовиків під Крутами. Відповідальність особистості $є$ складовою частиною соціальної відповідальності. Відповідальна особистість відчуває обов'язок перед сім'єю, трудовим колективом, державою, народом. На думку О.Ю. Кіріченко, поняття соціальної відповідальності є багаторівневим та проявляється на особистісному рівні через ступінь громадянської зрілості особистості, її світосприйняття, усвідомлення своєї значущості у державних та світових перетвореннях, іiї прагнення до них у всіх сферах життя [4, с. 12].

Про соціальну відповідальність українського суспільства за Соборність України свідчить наявність офіційного свята - Дня Соборності України (22 січня), формування історії якого пройшло близько 9 етапів у складні історичні, політичні та правові часи, які $\epsilon$ такими й сьогодні. Значення соціальної відповідальності українського суспільства має полягати також у обов'язках всіх і кожного перед собою та державою, що й буде запорукою розбудови національної держави, демократичного, патріотичного та соціально-орієнтованого суспільства, а також Соборної України.

\section{Література:}

1. Полонська-Василенко Н.Д. Історія України: у 2 т. Т. 2. Від середини 
2. Про День Соборності України: Указ Президента України від 13 листопада 2014 р. № 871/2014 / Президент України. Офіційний вісник Президента України. 2014. № 43. С. 44. Ст. 1961.

3. «Досить розділень»: Зеленський привітав українців 3 Днем Соборності. URL: https://www.ukrinform.ua/rubric-polytics/3175809-dositrozdilen-zelenskij-privitav-ukrainciv-z-dnem-sobornosti.html.

4. Кіріченко О.Ю., Куценко В.Й. Соціальна відповідальність як чинник сталого розвитку суспільства. Економіка і менеджмент 2016: перспективи інтегращії та інноваційного розвитку: матеріали між нар. наук.-практ. конф. (Дніпропетровськ, 14-15 квітня 2016 р.). Дніпропетровськ, 2016. С. 11-13.

DOI https://doi.org/10.30525/978-9934-26-040-7-7

\title{
КРИТЕРІЇ РОЗМЕЖУВАННЯ ПРАВА І МОРАЛІ
}

\author{
Кравцова М. О. \\ кандидат юридичних наук,
}

викладач кафедри загально-правових дисииплін

Донецького юридичного інституту

Міністерства внутрішніх справ Украӥни

м. Кривий Ріг, Дніпропетровська область, Украӥна

Приходько А. А.

кандидат юридичних наук,

старший викладач кафедри організачії досудового розслідування

факультету № 1

Криворізького навчально-наукового інституту

Донецького юридичного інституту

Міністерства внутрішніх справ України, капітан поліиіi

м. Кривий Ріг, Дніпропетровська область, Украӥна

Проблема співвідношення моралі і права, як показує загальний огляд теоретичних і літературних спроб ії осмислення, більше цікавила юристів, ніж етикою. Вона для них була і в значній мірі до теперішнього часу залишається однією 3 ключових в теорії права. 